\title{
PENGARUH KOMPETENSI PROFESIONAL DAN GAYA MENGAJAR GURU TERHADAP HASIL BELAJAR PADA MATA PELAJARAN EKONOMI
}

\author{
Sabrina Salsa Devi ${ }^{1}$, Mohamad Arief Rafsanjani ${ }^{2}$ \\ ${ }^{1}$ Universitas Negeri Surabaya, sabrinadevi16080554066@mhs.unesa.ac.id \\ ${ }^{2}$ Universitas Negeri Surabaya, mohamadrafsanjani@unesa.ac.id
}

DOI

https://doi.org/10.26740/jupe.v9n3.p90$\underline{95}$

\author{
Article history \\ Received \\ 24 May 2021 \\ Revised \\ 2 July 2021 \\ Accepted \\ 7 July 2021
}

\section{How to cite}

Devi, S. A., \& Rafsanjani, M. A. (2021). Pengaruh Kompetensi Profesional dan Gaya Mengajar Guru Terhadap Hasil Belajar Pada Mata Pelajaran. Jurnal Pendidikan Ekonomi (JUPE), 9(3), 9095.

https://doi.org/10.26740/jupe.v9n3.p9095

Kata Kunci: gaya mengajar, kompetensi profesional, hasil belajar Keywords: teaching style, professional competence, learning outcomes

\section{Corresponding author}

Sabrina Salsa Devi sabrinadevi16080554066@mhs.unesa.ac.id

\begin{abstract}
Abstrak
Penelitian ini bertujuan untuk menganalisis seberapa besar pengaruh kompetensi profesional dan gaya mengajar guru terhadap hasil belajar peserta didik pada mata pelajaran ekonomi. Penelitian ini akan meneliti dengan metode kuantitatif dengan sampel 158 peserta didik dari tiga SMA se-Kecamatan Driyorejo dengan menggunakan tingkat kesalahan 5\%. Teknik yang digunakan untuk mengumpulksn sampel merupakan teknik proportional stratified random sampling. Terdapat tahapan dalam analisis data adalah dengan analisis uji asumsi klasik, analisis regresi linier berganda, uji t dan uji koefisien determinasi. Hasil dari penelitian ini adalah kompetensi profesional dan gaya mengajar guru berpengaruh positif secara parsial terhadap hasil belajar peserta didik pada mata pelajaran ekonomi di SMA se- Kecamatan Driyorejo.
\end{abstract}

Abstract
The aims of the research is to analyze how much influence the
professional competence and teaching style of teachers have on student
learning outcomes in economic subjects. This study will examine
quantitative methods with a sample of 158 students from three high
schools in Driyorejo district using an error rate of 5\%. The technique
used to collect samples is a proportional stratified random sampling
technique. There are stages in data analysis, namely the classical
assumption test analysis, multiple linear regression analysis, t test and
test the coefficient of determination. The results of this study were the
professional competence and teaching style of teachers partially positive
effect on student learning outcomes in economics subjects in high
schools in Driyorejo district.

\section{Abstract}

The aims of the research is to analyze how much influence the professional competence and teaching style of teachers have on student learning outcomes in economic subjects. This study will examine quantitative methods with a sample of 158 students from three high technique. There are stages in data analysis, namely the classical assumption test analysis, multiple linear regression analysis, t test and test the coefficient of determination. The results of this study were the schools in Driyorejo district. 


\section{PENDAHULUAN}

Pendidikan merupakan suatu aspek penting yang perlu dicapai karena menyangkut hak-hak individu dalam mendapatkan ilmu yang berguna untuk masa depan. Landasan pokok sistem pendidikan Indonesia dituliskan dalam UUD 1945 Pasal 31 ayat (1) yang menuliskan bahwa setiap warga negara Indonesia berhak atas pendidikan. Dengan demikian, pendidikan merupakan hal yang penting untuk terus diteliti demi perkembangan masyarakat Indonesia Pendidikan juga disebut sebagai aspek penting dari pembangunan berkelanjutan yang mana nantinya melalui pendidikan ini diharapkan dapat memberantas kemiskinan dan meningkatkan kesejahteraan hidup masyarakat. Upaya yang beragam telah dilakukan oleh pemerintah, contohnya seperti program wajib belajar yang sebagaimana tercantum pada Undang-Undang Nomor 20 Tahun 2003 tentang Sistem Pendidikan Nasional yang membahas tentang pemerintah pusat bersama dengan pemerintah daerah akan bertanggung jawab atas pendidikan minimal yang wajib diikuti oleh semua warga negara Indonesia.

Era globalisasi ini memberi harapan tentang pendidikan yang akan menjadi tameng generasi muda untuk menghadapi arus global dunia luar. Menciptakan generasi muda penerus bangsa merupakan bagian dari arah pendidikan Indonesia yang tertulis di Undang-Undang Sistem Pendidikan Nasional No. 20 Tahun 2003. UndangUndang ini menyatakan bahwa fungsi dari pendidikan nasional adalah menciptakan perkembangan dalam hal keahlian dan karakter serta peradaban bangsa yang bermartabat untuk mencerdaskan kehidupan bangsa, serta memiliki tujuan untuk mengembangkan potensi peserta didik supaya menjadi individu dengan iman dan takwa, akhlak yang mulia, sehat, memiliki ilmu, cakap, kreatif, mandiri, dan warga negara yang menjunjung demokrasi serta mempunyai tanggung jawab.

Berdasarkan observasi awal yang dilakukan peneliti, menunjukkan bahwa beberapa guru yang ada di SMA se kecamatan driyorejo memiliki kompetensi dan gaya mengajar yang kurang baik dengan mata pelajaran ekonomi yang diajarkannya. Sebagai contoh, ada beberapa guru mata pelajaran ekonomi yang tidak menggunakan metode pembelajaran yang baik, tidak juga menggunakan media pembelajaran dan hanya memberikan tugas-tugas saja. Hal tersebut tidak sesuai dengan kurikulum yang digunakan yaitu kurikulum 2013. Akibatnya, banyak peserta didik yang mengeluh bahwa kegiatan pembelajaran tidak menarik, bahkan hal tersebut juga mengakibatkan hasil belajar peserta didik menurun.

Maksud dari adanya pembelajaran adalah untuk mencapai kompetensi yang ada di dalam kurikulum dengan skala penilaian hasil belajar. Hasil belajar adalah perwujudan atau pengukuran dari kemampuan potensial dan kapabilitas yang dimiliki oleh seorang manusia atau peserta didik. Tingkat hasil belajar seorang peserta didik mungkin dicerminkan melalui perilaku, termasuk perilaku kemampuan pengetahuan, kapabilitas dalam berpikir serta keterampilan motorik. (Caska \& Indrawati, 2014) mengatakan ada sejumlah faktor-faktor yang memiliki pengaruh terhadap tingkat kesuksesan proses belajar dan tingkat kualitas belajar peserta didik. Faktor-faktor itu diantaranya adalah kurikulum, guru, proses pendidikan, pemerintah, masyarakat, orang tua, dan sarana serta prasarana. Dalam mewujudkan kesuksesan proses pembelajaran dibutuhkan tenaga pendidik dan pengajar yang profesional. Unsur ini kemudian dikuatkan dengan argumen yang dinyatakan oleh (Hamalik, 2008). Argumen tersebut menyatakan bahwa kompetensi profesional yang dimiliki oleh seorang guru adalah salah satu kompetensi paling penting dalam kehidupan profesi seorang guru.. Guru sebagai tenaga yang bergerak di bidang profesional juga harus memiliki gaya mengajar yang digunakan untuk mengenali potensi anak didiknya.

Menurut (Usman \& Setiawati, 1993), gaya mengajar adalah rangkaian pelaksanaan kegiatan oleh guru dengan bentuk interaksi belajar-mengajar yang memiliki tujuan dalam memberantas rasa bosan yang dimiliki oleh peserta didik, yang juga memicu rasa tekun, antusias, dan penuh partisipasi oleh peserta didik. Penelitian yang dilaksanakan oleh (Djauhari, 2016) mendemonstrasikan cara mengajar guru dapat berperan positif kepada kebiasaan belajar, yang artinya semakin baik tingkat gaya mengajar guru, hasil belajar peserta didik juga akan mengalami perbaikan. (Deswita \& dahen, 2013) menunjukkan bahwa cara mengajar guru serta keinginan untuk belajar akan berbanding secara lurus terhadap hasil belajar akuntansi. Hasil penelitian tersebut juga sesuai dengan dengan argumen dari (Sabri, 2010) bahwa faktor penentu hasil belajar diklasifikasikan menjadi faktor dari eksternal dan internal, dan gaya mengajar termasuk ke dalam serta faktor dari luar diri. Sejalan dengan pendapat (Rusman, 2012) bahwa faktor yang yang memiliki pengaruh terhadap hasil belajar terdiri atas faktor internal dan eksternal. Unsur-unsur internal mencakup unsur psikologis dan fisiologis. Di lain sisi, faktor eksternal adalah faktor lingkungan yang diuraikan menjadi lingkungan fisik, lingkungan sosial, serta faktor instrumental atau faktor yang diharapkan memiliki fungsi untuk menjadi sarana agar rencana tujuan-tujuan pembelajaran dapat tercapai. Faktor instrumental dapat berbentuk seluruh hal yang diterapkan guru, baik gaya mengajar, kedisiplinan guru, kompetensi guru, kurikulum, dan sarana prasarana di Sekolah. Tingkat kesuksesan proses belajar-mengajar dari perspektif guru dapat dicerminkan oleh konsistensi guru dalam pemilihan gaya mengajar yang baik dan dapat membangun lingkungan 
belajar yang kondusif dan mempermudah peserta didik untuk menerima pembelajaran.

Selain dari gaya mengajar guru, kompetensi profesional guru juga dapat mempunyai pengaruh terhadap hasil belajar peserta didik. Menurut (Danim, 2003), kompetensi profesional adalah serangkaian kapabilitas yang dibutuhkan untuk menciptakan perwujudan seorang guru sebagai seorang profesional yang memiliki penguasaan dalam bidang mata pelajaran dan dapat memberikan bimbingan terhadap peserta didik dalam proses melampaui standar kompetensi. Kompetensi profesional telah tertuang pada Undang-Undang Republik Indonesia Nomor 14 Tahun 2005 tentang Guru dan Dosen. Undang-Undang ini membahas tentang empat kategori kompetensi guru, yaitu kompetensi pedagogik, kompetensi kepribadian, kompetensi profesional, dan kompetensi sosial. Penelitian yang diselenggarakan oleh (Rahayu F \& Thomas, 2017) memiliki hasil bahwa kompetensi profesional guru, minat belajar, dan motivasi belajar memiliki pengaruh kepada tingkat keberhasilan belajar peserta didik. Penelitian lainnya yang dilaksanakan oleh (Dewi et al., 2014) menyatakan bahwa kompetensi di bidang pedagogik bersamaan dengan kompetensi profesional secara simultan berbanding secara positif dan signifikan untuk peningkatan keberhasilan belajar peserta didik, terutama di mata pelajaran ekonomi.

Penelitian ini akan menggunakan variabel kompetensi profesional, gaya mengajar guru, serta hasil belajar peserta didik di mata pelajaran ekonomi. pada penelitian sebelumnya, belum meneliti pengaruh dari kompetensi profesional terhadap hasil belajar. Selain itu, peneliti ingin mengetahui bagaimana hasil belajar peserta didik se Kecamatan driyorejo yang dipengaruhi oleh gaya mengajar dan kompetensi profesional guru di Sekolah masing-masing mengingat belum ada penelitian yang meneliti hal tersebut. Pada penelitian sebelumnya menggunakan variabel gaya mengajar guru, disiplin belajar, teman sebaya, serta prestasi belajar. Bentuk populasi penelitian ini akan berbeda dari penelitianpenelitian sebelumnya. Populasi yang digunakan merupakan peserta didik dari tiga sekolah berbeda yang ada di Kecamatan Driyorejo, sampel yang digunakan sebanyak 158 peserta didik dan teknik pengambilannya dengan teknik proporsional stratified random sampling . Sedangkan pada penelitian sebelumnya populasi yang digunakan peserta didik kelas XI IPS SMA Negeri 1 Bawang tahun ajaran 2016/2017, jumlah sampel sebanyak 144 peserta didik dan teknik pengambilannya dengan teknik sampling jenuh.

Berdasarkan permasalahan diatas, penulis bermaksud untuk melihat dan menganalisis seberapa besar kompetensi profesional dan gaya mengajar guru berpengaruh pada hasil belajar anak didiknya dengan gaya mengajar yang dimilikinya sebagai bagian dari proses interaksi positif dalam proses pembelajaran. Temuan penelitian ini diharapkan mampu berkontribusi terhadap pertumbuhan kajian dalam ilmu pendidikan, khususnya yang berhubungan dengan kompetensi profesional dan gaya mengajar guru.

\section{METODE}

Dalam praktiknya, penelitian ini akan meneliti melalui metode kuantitatif dengan jumlah sampel 158 peserta didik yang berasal dari tiga SMA se-Kecamatan Driyorejo, dengan menggunakan tingkat kesalahan 5\%. Penelitian ini memberlakukan teknik proporsional stratified random sampling untuk mengumpulkan sampel.

Data untuk analisis dikumpulkan menggunakan tiga teknik, yaitu wawancara, angket/ kuesioner dan dokumentasi. Wawancara dalam pengumpulan data ini berfungsi untuk mengumpulkan informasi di tingkat awal mengenai masalah tentang kompetensi profesional, gaya mengajar, dan minat belajar peserta didik. Dalam mengumpulkan data untuk nilai hasil belajar peserta didik peneliti menggunakan jenis angket terbuka, sedangkan untuk kompetensi profesional dan gaya mengajar guru menggunakan Angket/kuesioner berupa pernyataan tertutup dimana alternatif jawaban telah disediakan dengan menggunakan skala likert 1-5 dengan gradien dari negatif sampai positif sebagai skala pengukuran yang dibuat dalam bentuk checklist. Pada penelitian ini, Indikator kompetensi profesional yang digunakan diantaranya yaitu: (1) memiliki penguasaan terhadap landasan pendidikan, (2) memiliki penguasaan terhadap bahan pengajaran, (3) kemampuan dalam penyusunan program pengajaran, (4) menilai hasil dan proses pembelajaran (M. uzer Usman, 2006). Untuk indikator gaya mengajar guru yang digunakan diantaranya yaitu: (1) gaya penampilan guru, (2) hubungan guru dengan peserta didik, (3) memberi motivasi, (4) memberi variasi, (5) menjelaskan pelajaran, (6) memberi penguatan (Astutie, 2012). Sementara itu, indikator yang digunakan sebagai acuan hasil belajar merupakan nilai dari hasil belajar ulangan harian pada materi pasar modal.

Pengukuran akan melalui analisis regresi berganda dengan tujuan mengukur data. Selanjutnya akan digunakan beberapa Teknik uji asumsi klasik, diantaranya yaitu uji normalitas, uji multikolinearitas, uji heteroskedastisitas, uji autokorelasi. Kemudian, dilanjutkan pengukuran uji hipotesis melalui uji t dan uji F, dan uji koefisien determinasi (R2) dengan tujuan mengetahui besarnya prosentase pengaruh kedua variabel bebas terhadap variabel terikat . 


\section{HASIL DAN PEMBAHASAN \\ HASIL}

Berdasarkan data yang telah diambil dan diolah oleh peneliti, didapatkan nilai hasil belajar peserta didik beserta rata-ratanya:

Tabel 1. Nilai Hasil Belajar

\begin{tabular}{ccc}
\hline $\begin{array}{c}\text { Jenis } \\
\text { kelamin }\end{array}$ & Jumlah & Rata-rata \\
\hline Pria & 71 & 68.8028 \\
Wanita & 87 & 70.7471
\end{tabular}

(Sumber: data diolah peneliti, 2020)

Berdasarkan langkah-langkah penelitian yang telah dilaksanakan, peneliti memperoleh data yang berupa kompetensi profesional, gaya mengajar guru, serta hasil belajar peserta didik di mata pelajaran ekonomi di SMA Se Kecamatan Driyorejo. Kemudian dilanjutkan dengan melakukan uji asumsi klasik, dengan tahap uji normalitas, uji multikolinieritas, uji heteroskedastisitas, dan uji autokorelasi.

Dilanjutkan uji hipotesis yang tersusun dari: uji t yang dipakai untuk mendapatkan informasi terkait adanya pengaruh antara variabel bebas (X) terhadap variabel terikat (Y). Perolehan kesimpulan pada uji ini adalah apabila tingkat signifikan $<0,05$, kesimpulannya adalah ditemukan pengaruh variabel independen pada variabel dependen. Di lain sisi, apabila nilai signifikan > 0,05 artinya tidak ditemukan pengaruh semua variabel bebas terhadap variabel terikat.

Uji normalitas melalui penggunaan metode Kolmogorov-Smirnov menunjukkan nilai Asymp.Sig.(2tailed) lebih besar ( $>$ ) dari level of significant $\alpha=5 \%$. Pada variabel kompetensi profesional nilai Asymp.Sig.(2-tailed) $56 \%$, gaya mengajar dengan angka $70.3 \%$, dan hasil belajar sebesar $8.7 \%$. artinya, data yang digunakan terdistribusi normal. Pada uji multikolinieritas dengan metode Variance Inflation Factor (VIF). Nilai VIF dari variabel kompetensi dan gaya mengajar sebesar 1.225. artinya, kedua variabel terbebas dari asumsi multikolinieritas karena nilainya < 10,00 .

Pada uji heteroskedastisitas menggunakan scatterplot diketahui bahwa data yang ada tidak menampilkan gejalagejala heteroskedastisitas. Fakta ini disebabkan gugusan data yang tersebar di bagian atas serta di bagian bawah, ataupun berada di sekeliling angka 0, dan tidaknya terbentuk kumpulan titik-titik data, sekadar di bagian atas atau di bagian bawah angka 0 . Uji autokorelasi melalui uji Durbin-Watson (DW) memiliki ukuran untuk data yang digunakan terbebas dari autokorelasi karena nilai DurbinWatson dengan angka 1.841 berada diantara 1.65 dan 2.35 .

Dari uji $\mathrm{t}$ (parsial) kompetensi profesional menunjukkan nilai t hitung dengan angka 13,854 dan nilai signifikan dengan besaran $0,00<0,05$ yang artinya kompetensi profesional mempunyai pengaruh signifikan pada hasil belajar peserta didik. Variabel gaya mengajar menampilkan nilai $\mathrm{t}$ hitung dengan angka 3,669 dan nilai signifikan dengan angka $0,00<0,05$. Angka ini memiliki arti bahwa gaya mengajar terbukti mempunyai pengaruh yang terlihat signifikan untuk hasil belajar peserta didik.

Tabel 2. Hasil Uji t

\begin{tabular}{|c|c|c|c|c|c|}
\hline & \multirow[b]{2}{*}{ Model } & \multicolumn{2}{|c|}{$\begin{array}{l}\text { Unstandardized } \\
\text { Coefficients }\end{array}$} & \multirow[b]{2}{*}{$\mathrm{t}$} & \multirow[b]{2}{*}{ Sig. } \\
\hline & & B & $\begin{array}{l}\text { Std. } \\
\text { Error }\end{array}$ & & \\
\hline \multirow[t]{3}{*}{1} & (Constant) & 22.442 & 3.026 & 7.417 & .000 \\
\hline & $\begin{array}{l}\text { Kompetensi } \\
\text { Profesional }\end{array}$ & 10.657 & .769 & $\begin{array}{r}13.85 \\
4 \\
\end{array}$ & .000 \\
\hline & Gaya Mengajar & 3.002 & .818 & 3.669 & .000 \\
\hline
\end{tabular}

(Sumber: data diolah peneliti, 2020)

Untuk uji koefisien determinasi menampilkan nilai Adjusted R square dengan nilai 0,659 maka nilai pada R2 $0,659 \times 100 \%=65,9 \%$ yang berarti bahwa variabel bebas (X) berpengaruh sebesar $65,9 \%$ terhadap hasil belajar (Y). Sisa dari persentase tersebut diisi dengan bentuk faktor lainnya yang tidak diukur sebagai variabel.

Tabel 3. Hasil Adjusted R Square

\begin{tabular}{ccrrrr}
\hline $\begin{array}{c}\text { Mod } \\
\text { el }\end{array}$ & $\mathrm{R}$ & $\begin{array}{c}\mathrm{R} \\
\text { Square }\end{array}$ & $\begin{array}{c}\text { Adjusted } \\
\text { R Square }\end{array}$ & $\begin{array}{c}\text { Std. Error } \\
\text { of the } \\
\text { Estimate }\end{array}$ & $\begin{array}{l}\text { Durbin- } \\
\text { Watson }\end{array}$ \\
\hline 1 & $.814^{\mathrm{a}}$ & .663 & .659 & 6.23717 & 1.841 \\
\hline
\end{tabular}

(Sumber: data diolah peneliti, 2020)

\section{PEMBAHASAN}

Pengaruh Kompetensi Profesional Terhadap Hasil Belajar Peserta Didik Pada Mata Pelajaran Ekonomi Di SMA Se Kecamatan Driyorejo

Didasarkan kepada sejumlah tahapan penelitian yang dilaksanakan, hasilnya variabel kompetensi profesional menampilkan nilai t hitung dengan nilai 13,854 dengan nilai signifikan dengan nilai $0,00<0,05$, artinya ada pengaruh positif kompetensi profesional terhadap hasil belajar peserta didik pada mata pelajaran ekonomi. Penelitian ini menampilkan adanya peningkatan kompetensi kompetensi profesional yang dimiliki guru akan diikuti oleh peningkatan hasil belajar peserta didik. Temuan ini selaras dengan (Rahayu F \& Thomas, 2017) dengan argumen kompetensi profesional guru dan minat belajar memiliki pengaruh baik secara langsung maupun tidak langsung dengan peran dorongan untuk belajar kepada hasil belajar. Penguasaan landasan pendidikan akan mengarahkan guru dalam pelaksanaan pembelajaran yang sejalan dengan tujuan yang ditentukan, sejalan 
dengan kurikulum yang diberlakukan, dan melalui proses penyesuaian kebutuhan dan kondisi peserta didik. Guru yang menguasai bahan pengajaran sesuai kompetensi akan dapat menyalurkan pelajaran dengan efektif kepada peserta didik, lalu dapat mengarahkan peserta didik dalam eksplorasi pengetahuan yang dikuasainya. Penyusunan dan pelaksanaan program pengajaran yang baik disertai dengan penilaian proses dan hasil pembelajaran akan memudahkan guru atas tercapainya tujuan pembelajaran yang maksimal. Temuan ini sesuai dengan teori belajar behavoiristik dengan pandangan bahwa hasil belajar tidak memiliki pengaruh yang disebabkan kapabilitas internal manusia (insight), namun disebabkan stimulan-stimulan yang menciptakan respon. Kegiatan belajar peserta didik di kelas mampu menghasilkan pengaruh secara optimal jika stimulan dirangkai agar mudah mendapatkan respon dari peserta didik. Stimulus disini dapat berasal dari guru melalui pembelajaran yang dilakukan. Stimulus erat kaitannya dengan kompetensi profesional guru, karena guru dengan kompetensi profesional yang baik akan mampu memilih stimulan yang efektif untuk peserta didik sehingga peserta didik menciptakan respon positif terhadap apa yang sedang dipelajarinya. Argumen ini juga dinyatakan oleh (Sudjana, 2014) bahwa hasil belajar peserta didik juga ditentukan unsur eksternal bagi peserta didik atau disebut juga sebagai faktor lingkungan. Unsur lingkungan yang banyak pengaruhnya adalah kualitas pengajaran. Kualitas pengajaran dipengaruhi oleh kompetensi profesional yang dikuasai seorang guru. Penelitian ini juga dikuatkan oleh penelitian (Muzenda, 2013) yang menyatakan bahwa penguasaan materi yang dimiliki guru berpengaruh pada hasil belajar peserta didik, dimana penguasaan materi adalah bagian dari komponen kompetensi profesional.

Kompetensi profesional yang dimiliki seorang guru dapat menjadi krusial dalam korelasi dengan aktivitas bersama prestasi belajar peserta didik. Proses pembelajaran serta prestasi belajar dari peserta didik tidak sekadar dipengaruhi oleh sekolah, pola, struktur, dan isi kurikulumnya. Namun, mayoritas penyebab hal ini merupakan kompetensi guru dalam pengajaran dan dan pemberian bimbingan kepada mereka. Temuan penelitian tersebut sesuai dengan temuan dari (Gidot et al., 2015) bahwa kompetensi profesional guru dan minat belajar mempengaruhi hasil belajar dengan positif dan signifikan. Temuan penelitian tersebut memiliki jalan yang sesuai argumen dari (Sudjana, 2014) bahwa hasil belajar ditentukan dua faktor utama, yaitu faktor internal dan faktor eksternal. Faktor eksternal adalah unsur yang datang dari luar diri peserta didik merupakan faktor lingkungan dengan cakupan kompetensi profesional guru. Argumen yang sama juga juga dinyatakan oleh (Slameto, 2003) yang menyebutkan bahwa faktor internal dan faktor eksternal akan memberikan pengaruh terhadap aktivitas belajar. Faktor eksternal termasuk metode mengajar dimana merupakan komponen dari kompetensi profesional guru.

\section{Pengaruh Gaya Mengajar Guru Terhadap Hasil Belajar Peserta Didik Untuk Mata Pelajaran Ekonomi SMA Se-Kecamatan Driyorejo}

Berdasarkan tahapan penelitian yang dilakukan, hasilnya variabel kompetensi gaya mengajar guru menampilkan nilai t hitung dengan angka 3,669 dan nilai signifikan yang bernilai $0,00<0,05$ yang artinya ada pengaruh positif antara gaya mengajar guru terhadap hasil belajar peserta didik untuk mata pelajaran ekonomi. Temuan pengukuran ini mengindikasikan adanya perbandingan lurus antara gaya mengajar guru dengan hasil belajar peserta didik. Temuan ini juga seimbang dengan temuan dari (Khumaero \& Arief, 2017). Penelitian tersebut menjelaskan bahwa gaya mengajar guru berpengaruh kepada prestasi belajar pada mata pelajaran ekonomi kelas XI IPS SMAN 1 Bawang. Temuan ini juga sesuai terhadap temuan oleh (Astutie, 2012) yang membuktikan adanya pengaruh gaya mengajar secara signifikan terhadap hasil belajar peserta didik secara parsial dan prestasi belajar peserta didik juga diatribusikan kepada faktor guru serta kegiatan pengajaran. Unsur tersebut kemudian dikuatkan dengan argumen yang dinyatakan oleh (Hartono, 2013) guru yang mampu mengajar dengan baik tentu akan menghasilkan kualitas peserta didik yang baik pula. Kualitas peserta didik yang baik dapat dilihat dari segi akademik maupun non akademik. Maka dari itu dalam mengajar guru dituntut mempunyai gaya mengajar yang dapat membuat peserta didik tertarik dengan pelajaran tersebut agar tujuan pembelajaran dapat dicapai dengan maksimal. Peserta didik akan mampu menyerap pelajaran dengan baik dan jika guru dapat menyampaikan pelajaran sesuai dengan kondisi peserta didik.

Seorang guru dengan kompetensi profesional menguasai kemampuan yang lebih dalam membangun situasi belajar yang efektif, membuat senang, serta memungkinkan adanya kemampuan yang lebih dalam melakukan pengelolaan kelas, sehingga kegiatan pembelajaran mencapai posisi optimal. Penelitian ini juga sesuai dengan temuan (Annisa et al., 2018), bahwa gaya mengajar guru dan cara guru menerapkan disiplinnya berpengaruh ke hasil belajar peserta didik untuk mata pelajaran ekonomi XII IPS. Guru diharapkan selalu memberikan gaya mengajar yang bervariasi yang selaras terhadap bentuk pembelajaran serta sesuai dengan situasi peserta didik pada jalannya belajar mengajar agar kebosanan mampu dihindarkan. Berdasarkan hal tersebut, peserta didik akan lebih mempunyai semangat serta 
ketertarikan dalam aktivitas pembelajaran, serta hasil belajar yang dicapai akan optimal. Hal tersebut juga diperkuat dengan pernyataan (Suparman, 2010) yang menyatakan bahwa bagi peserta didik adanya gaya mengajar guru dilihat sebagai suatu yang positif, energik, bersemangat, menyenangkan, dan semuanya memiliki hubungan yang erat terhadap pencapaian hasil belajar yang maksimal.

\section{SIMPULAN}

Berdasarkan pada pemaparan hasil penelitian, penelitian ini mempunyai beberapa kesimpulan, yaitu: (1) kompetensi profesional memiliki pengaruh positif dalam tingkatan hasil belajar peserta didik untuk mata pelajaran ekonomi, (2) gaya mengajar guru memiliki pengaruh positif dalam hasil belajar peserta didik untuk mata pelajaran ekonomi.

Kompetensi profesional bersama gaya mengajar yang sesuai diharapkan menjadi komponen yang ada di kinerja setiap guru Indonesia. Hal ini disebabkan kedua unsur tersebut memiliki peran yang krusial dalam pembangunan hasil belajar peserta didik. Kompetensi profesional bersamaan dengan gaya mengajar yang ditingkatkan dapat berbanding positif dalam upaya peningkatan hasil belajar peserta didik. Saran yang dapat diterapkan untuk penelitian selanjutnya adalah menambah teori tentang variabel yang mirip serta menguraikan unsurunsur lain yang dapat menentukan hasil belajar peserta didik agar penelitian yang dihasilkan menjadi lebih sempurna dan beragam.

\section{DAFTAR PUSTAKA}

Annisa, N., Caska, \& Kartikowati, S. (2018). Pengaruh Gaya Mengajar Guru Dan Disiplin Mengajar Guru Terhadap Hasil Belajar Siswa Pada Mata Pelajaran Ekonomi Siswa Ips Kelas Xi Sma Ylpi Pekanbaru. JOM FKIP, 5, 1-12.

Astutie, C. S. A. (2012). Pengaruh Gaya Mengajar Guru Dan Gaya Belajar Siswa Terhadap Hasil Belajar Mata Pelajaran Ekonomi Di Kelas X Sma Negeri 18 Surabaya. Jurnal Fakultas Ekonomi, Universitas Negeri Surabaya, 20, 1-15.

Caska, \& Indrawati, H. (2014). Optimalisasi Hasil Belajar Ekonomi Koperasi Sekolah Menengah Atas (SMA) Melalui Problem Based Learning (PBL) Di Kota Pekanbaru. Jurnal Pendidikan, 5.

Danim, S. (2003). Agenda pembaharuan sistem pendidikan. Pustaka Pelajar.

Deswita, atika prama, \& dahen, lovelly dwinda. (2013). Pengaruh Persepsi Siswa Tentang Gaya Mengajar Guru Dan Minat Belajar Siswa Terhadap Hasil Belajar Akuntansi Pada Program KEAHLIAN AKUNTANSI SISWA KELAS X DI SMKN 1 Sawahlunto. Journal of Economic and Economic Education Vol.2 No.1 (1-10), 2(1), 1-10.

\author{
file:///G:/SEMINAR PROPOSAL/JURNAL GAYA \\ MENGAJAR TERHADAP HASIL \\ BELAJAR/jurnal atika.pdf
}

Dewi, luh retiantari, Suharsono, N., \& Haris, I. akhmad. (2014). Pengaruh Kompetensi Pedagogik Dan Kompetensi Profesional Terhadap Hasil Belajar Siswa Dalam Mata Pelajaran Ekonomi Kelas X Sman 4 Singaraja.4(1), 1-11. file:///D:/revisi artikel tgl 15 des/kompt prof thdp hsl bljr.pdf

Djauhari, A. (2016). Pengaruh Gaya Mengajar Guru Dan Kebiasaan Belajar Terhadap Hasil Belajar ( Studi Pada Mata Pelajaran Ips Peserta Didik Di Smp Negeri Satu. Penelitian Dan Pendidikan IPS (JPPI), 10(3), 310-321.

Gidot, S., Mashudi, \& Matsun, J. . (2015). Pengaruh Kompetensi Profesional Guru Dan Minat Belajar Terhadap Hasil Belajar Akuntansi Siswa Kelas XI. Jurnal Pendidikan Bisnis Dan Manajemen, 1(2).

Hamalik, O. (2008). Perencanaan Pengajaran Berdasarkan Pendekatan Sistem. Bumi Aksara.

Hartono, R. (2013). Ragam Model Mengajar Yang Mudah Diterima Murid. DIVA press.

Khumaero, L. Al, \& Arief, S. (2017). Pengaruh Gaya Mengajar Guru, Disiplin Belajar, Dan Teman Sebaya Terhadap Prestasi Belajar. Economic Education Analysis Journal, 6(3).

Muzenda, A. (2013). Lecturers' Competences And Students' Academic Performance. International Journal of Humanities And Social Science Invention $3,3(1), 6-13$.

Rahayu F, T., \& Thomas, P. (2017). Pengaruh Kompetensi Profesional Guru Dan Minat Belajar Terhadap Hasil Belajar Siswa Melalui Motivasi Belajar Sebagai Variabel Intervening Pada Mata Pelajaran Ekonomi. Economic Education Analysis Journal, 6(3), 711-726.

Rusman. (2012). Model-Model Pembelajaran. PT. Raja Grafindo Persada.

Sabri, M. A. (2010). Psikologi Pendidikan. Pedoman Ilmu Jaya.

Slameto. (2003). Belajar dan Faktor-faktor Yang Mempengaruhinya. Rineka Cipta.

Sudjana, N. (2014). Dasar-dasar proses belajar mengajar. Sinar Baru Algesindo.

Suparman. (2010). Gaya Mengajar yang Menyenangkan Siswa. Pinus Book Publisher.

Usman, M. uzer, \& Setiawati, L. (1993). Upaya Optimalisasi Kegiatan Belajar Mengajar. PT. Remaja Rosdakarya. 